\title{
Effect of Cultivation Time and Medium Condition in Production of Bacterial Cellulose Nanofiber for Urease Immobilization
}

\author{
M. Pesaran, ${ }^{1,2}$ Gh. Amoabediny, ${ }^{1,2,3}$ and F. Yazdian ${ }^{1}$ \\ ${ }^{1}$ Department of Life Science Engineering, Faculty of New Sciences and Technologies, University of Tehran, P.O. Box 14395-1561, \\ Tehran, Iran \\ ${ }^{2}$ Department of Bioreactor Engineering, Research Center for New Technologies in Life Science Engineering, University of Tehran, \\ P.O. Box 14395-1374, Tehran, Iran \\ ${ }^{3}$ Department of Chemical Engineering, Faculty of Engineering, University of Tehran, P.O. Box 11155-4563, Tehran, Iran
}

Correspondence should be addressed to Gh. Amoabediny; amoabediny@ut.ac.ir

Received 28 August 2015; Revised 14 November 2015; Accepted 16 November 2015

Academic Editor: Angela F. Jozala

Copyright (C) 2015 M. Pesaran et al. This is an open access article distributed under the Creative Commons Attribution License, which permits unrestricted use, distribution, and reproduction in any medium, provided the original work is properly cited.

\begin{abstract}
A new nanoporous biomatrix originated from bacterial resources has been chosen for urease immobilization. Urease has been immobilized on synthesized bacterial cellulose nanofiber since this enzyme has a key role in nitrogen metabolism. Gluconacetobacter xylinum ATCC 10245 has been cultivated for synthesis of a nanofiber with the diameter of 30-70 nm. Different cultivation processes in the aspect of time and cultivation medium conditions were chosen to study the performance of immobilized enzyme on four types of bacterial cellulose nanofibers (BCNs). Urease immobilization into the nanofiber has been done in two steps: enzyme adsorption and glutaraldehyde cross-linking. The results showed that the immobilized enzymes were relatively active and highly stable compared to the control samples of free enzymes. Optimum pH was obtained 6.5 and 7 for different synthesized $\mathrm{BCNs}$, while the optimum temperature for immobilized urease was $50^{\circ} \mathrm{C}$. Finding of the current experiment illustrated that the immobilized enzyme in optimum condition lost its initial activity by $41 \%$ after 15 weeks.
\end{abstract}

\section{Introduction}

By the 1990s, the progress of nanotechnology has been followed by the growth of nanobiotechnology. Initially, the nanotechnology and biotechnology were simply fused without generating any synergistic benefits, while later effective interactions between these two technologies have resulted in advanced developments. One typical example is "nanobiocatalysis," in which enzymes are immobilized on various nanostructured materials by using conventional approaches, like simple adsorption and covalent attachment.

Nanostructured materials have been used as hosts for enzyme immobilization to improve the performance of enzymes in various biocatalytic processes [1]. Among all nanostructured supports, nanofibers are distinguished as a good support for the immobilization of enzymes due to their high surface area-to-volume ratio and less mass transfer resistance. Moreover their recycling is easier in comparison to the other nanostructure materials $[2,3]$. In the last few decades, the cellulosic nanocomposites have been considered as an innovative solution to produce materials with advanced properties [4]. In addition, they have appeared as promising candidates for nanocomposites, due to their continuous nature and their nanoscaled diameters and high crystallinity.

The performance of enzyme immobilization strongly depends on the properties of support, such as material type, composition, structure, and mechanical properties. Better support properties provide a good mechanical strength, which can contribute to stability and reusability. The use of nanosized supports in enzyme immobilization is not only to enhance the stability and reusability of immobilized enzyme activity due to the presence of high surface area per volume ratio. In other words, high surface area of nanosized support provides a high number of functional groups on the surface support. Thus, CNF (Cellulose Nanofibers) have more chance of interacting with enzyme molecules [5-8].

Recently a great interest has been devoted to produce the cellulose fibers by using the novel processes like 
biotechnology techniques, which will reduce the environmental impacts. Studies reported that bacterial cellulose or biocellulose (BC) could be a better choice for cellulose products manufacturing [9].

Enzyme immobilization is a special technique to solve enzymatic problems (especially in the application of native enzyme), such as stability, reusability, and decline of activity due to inhibition by either medium or products [10]. The immobilization of enzyme is influenced by the properties of support, such as material type, composition, structure, and mechanical properties [11]. Enhanced support properties offer a good mechanical strength, which can contribute to stability and reusability. Nanosized supports are utilized not only to improve the stability and reusability of the immobilized enzyme but also to overcome their lower immobilized enzyme activity owing to presence of high surface area per volume ratio [12]. In other words, high surface area of nanosized support provides a high number of functional groups on the surface support [4].

Urease is an enzyme which catalyses the hydrolysis of urea. It is related to protein intake, nitrogen metabolism and excretion as follows (1). Many applications have been reported for immobilized urease in the literature [13], such as blood detoxification in artificial kidneys, the removal of urea from beverages and foods in food industry, and the reduction of urea content in effluent treatment in agriculture:

$$
\begin{aligned}
\left(\mathrm{NH}_{2}\right)_{2} \mathrm{CO}+3 \mathrm{H}_{2} \mathrm{O} \stackrel{\text { (UREASE) }}{\longrightarrow} & \mathrm{HCO}_{3}^{-}+2 \mathrm{NH}_{4}{ }^{+} \\
& +\mathrm{OH}^{-}
\end{aligned}
$$

There are many methods for enzyme immobilization including the adsorption, entrapment, and covalent binding [14]. Among them, the entrapment in nanofiber matrixes has been done by cross-linking reaction between enzyme molecules [15]. It made the catalysts stable with high retention of activity [16]. In addition, it should be noted that urease immobilization on bacterial cellulose nanofiber (BCN) and investigations on this novel biomolecule have been conducted for the first time in current study. In this research, the impact of different culture medium and various cultivation times on $\mathrm{BCN}$ biosynthesis has been examined to improve the urease immobilization results. Altering the conditions of $\mathrm{BCN}$ biosynthesis resulted in different behavior of immobilized urease in different temperatures and pHs. Furthermore, the immobilized urease showed different stability and reusability in these experiments. Results showed that regulating the biosynthesis parameters will affect the immobilized urease activity and stability. Statistical analysis was done as well. The effect of variables on urease activity was considered based on $P$ value.

\section{Materials and Methods}

2.1. Materials. The consumed materials in current study, urea, $\mathrm{NaOH}$, glutaraldehyde, and all other chemicals with analytical grade were purchased from Sigma-Aldrich. Besides that, the utilized urease (E.C. 3.5.1.5) was also the TYPE IX from jack bean provided by Sigma-Aldrich. Citric acid,
TABLE 1: Different BCN types as biomatrices used for urease immobilization.

\begin{tabular}{lcc}
\hline Cultivation time (day) & Cultivation medium & BCN type \\
\hline 7 & HS medium & $(\mathrm{A})$ \\
15 & HS medium & $(\mathrm{B})$ \\
7 & Molasses & $(\mathrm{C})$ \\
15 & Molasses & $(\mathrm{D})$ \\
\hline
\end{tabular}

magnesium sulfate, and bovine serum were prepared from Merck.

2.2. Nanofiber Synthesis and Its Characterization. Gluconacetobacter xylinum ATCC 10245 was the strain which was used for our experiments (provided by Collection of Scientific and Industrial Research Center, Tehran, Iran).

The Schramm and Hestrin medium (HS medium), including $20 \mathrm{~g}$ glucose, $5 \mathrm{~g}$ yeast extract, $5 \mathrm{~g}$ peptone, $3.3 \mathrm{~g}$ sodium hydrogen phosphate, $1.15 \mathrm{~g}$ citric acid, and $0.5 \mathrm{~g}$ magnesium sulfate for each liter of distillated water, was used with initial $\mathrm{pH}$ of 5 [17]. Cultivations have been done for 7 and 15 days which were classified as BCNs as (A) and (B), respectively.

On top of that, a mixture of $110 \mathrm{~g}$ molasses and $80 \mathrm{~mL}$ CSL (purchased from Glucosan company, Tehran, Iran) with $1.15 \mathrm{~g}$ citric acid and $2.7 \mathrm{~g}$ sodium hydrogen phosphate (purchased from Merck, Germany) per litter of distilled water was used to cultivate Gluconacetobacter xylinum in 7 and 15 days to produce BCNs of $(\mathrm{C})$ and $(\mathrm{D})$ types, respectively. Four different employed mediums are illustrated in Table 1.

Philips XL-30 was used to obtain SEM images $(3.5 \mathrm{~nm}$ at $30 \mathrm{kV}$ and $25 \mathrm{~nm}$ at $1 \mathrm{kV}$ ). The powder sample was fixed on a copper slide and coated with a thin layer of gold under vacuum.

2.3. BCN Purification. The samples were purified using boiling water and $0.1 \mathrm{M}$ sodium hydroxide for about 90 minutes and then rinsed with distilled water [18]. Thereafter, they were dried at room temperature for 2-3 days and maintained for tensile tests. Moreover, the regenerated cellulose nanofiber was oxidized according to the study of Huang et al. [19] as shown in Figure 1. The oxidation process was done by using $4.2 \mathrm{mg} \mathrm{mL}^{-1}$ of $\mathrm{NaIO}_{4}$ Solution (pH 6.1) at $30^{\circ} \mathrm{C}$ in a shaking water bath for $7 \mathrm{~h}$ in order to produce aldehyde groups on the fibers. Lastly, the nanofiber was washed with deionized water and dried under vacuum at $60^{\circ} \mathrm{C}$.

2.4. Immobilization of Urease. The urease solution $\left(2 \mathrm{mg} \mathrm{mL}^{-1}\right)$ was prepared in phosphate buffer $(\mathrm{pH}=7$, concentration of $30 \mathrm{mM}$ ). $2 \mathrm{~mL} \mathrm{mg}^{-1}$ of the urease solution was dropped on BCN sheet and remained for $3 \mathrm{~h}$ at room temperature $\left(25^{\circ} \mathrm{C}\right)$. Subsequently the glutaraldehyde solution with concentration of $0.75 \% \mathrm{w} / \mathrm{v}$ was added to the urease solution on the mentioned nanofiber sheet for $17 \mathrm{~h}$. To finalize the immobilization, the BCN sheet was washed by phosphate buffer and vortexed for about $10 \mathrm{~min}$. 


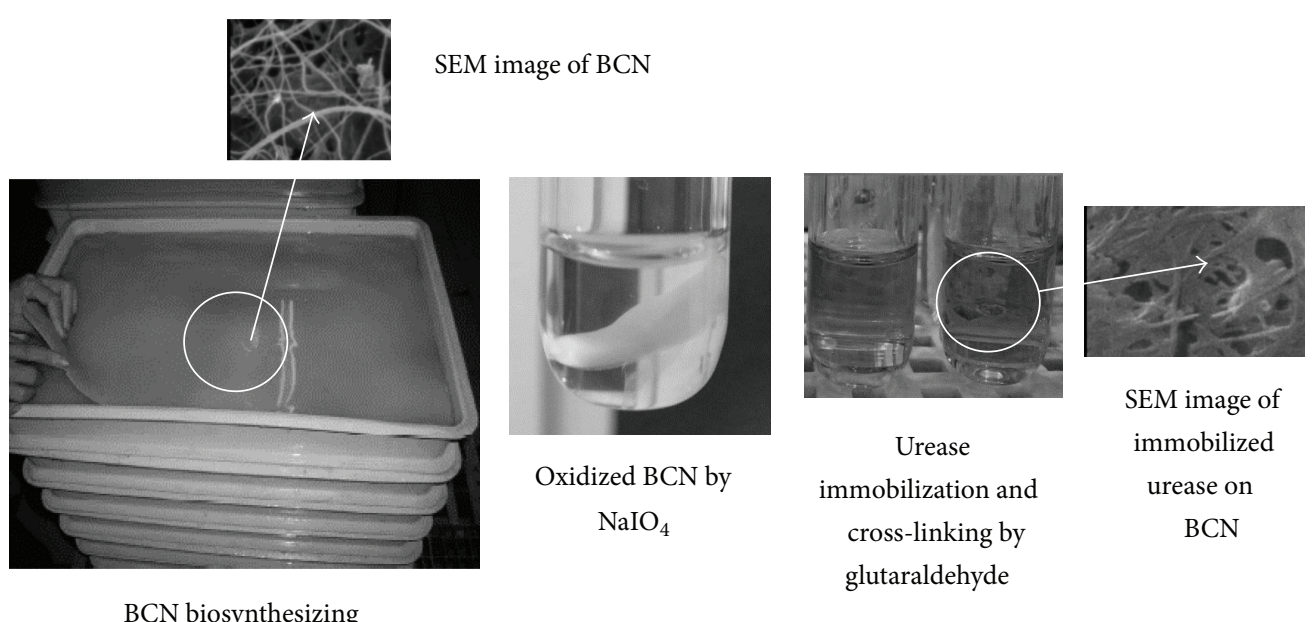

FIGURE 1: Diagram of BCN preparation and urease immobilization.

2.5. Urease Activity Assay. Urease activity was determined using the Berthelot method [20]. As mentioned in the literature 10 microliters of urea $(1.1 \mathrm{mM}), 1.94 \mathrm{~mL}$ of phosphate buffer ( $\mathrm{pH} 7,50 \mathrm{mM}$ ), and $50 \mathrm{~mL}$ of urease solution were added to the test tube. The mixture was shaken for $10 \mathrm{~min}$ at $37^{\circ} \mathrm{C}$ and then phenol reagent $(0.5 \mathrm{~mL})$ and hypochloride reagent $(0.5 \mathrm{~mL})$ were added to the above mixture. Next, it was shaken for $10 \mathrm{~min}$ at $55^{\circ} \mathrm{C}$ and cooled. Urease activity was determined spectrophotometrically at $630 \mathrm{~nm}$. In this stage of study, to achieve the standard curve, different concentrations of ammonium chloride solution were examined. Urease immobilized cellulose nanofiber activities were measured by the above procedure. $50 \mathrm{~mL}$ of phosphate buffer $(\mathrm{pH} 7$, $50 \mathrm{mM}$ ) was utilized instead of urease solution and urease immobilized cellulose nanofibers were consumed as immobilized urease. One unit of enzyme activity was defined as the amount of enzyme which can hydrolyze $1 \mu \mathrm{mol}$ urea per minute at $37^{\circ} \mathrm{C}$ under the assay conditions.

2.6. Determination of Protein Content. In this study, the protein content has been determined by the method of Bradford [21]. The test solution $(0.1 \mathrm{~mL})$ which contained immobilized urease was added to $2 \mathrm{~mL}$ of Coomassie Brilliant Blue solution produced a blue complex with the proteins. After $10 \mathrm{~min}$ of incubation at room temperature, the absorbance was measured at $595 \mathrm{~nm}$, against an albumin standard solution of BSA (0.01-0.15 $\left.\mathrm{mg} \mathrm{mL}^{-1}\right)$. This solution was prepared by adding $40 \mathrm{mg}$ of Coomassie Brilliant Blue G-250 dissolved in $50 \mathrm{~mL} \mathrm{95 \%} \mathrm{ethanol} \mathrm{and} 55 \mathrm{~mL} \mathrm{88 \%} \mathrm{H}_{3} \mathrm{PO}_{4}$. The resulting solution was diluted to a final volume of 1 liter.

2.7. Immobilized Enzyme Stability. In order to determine the reusability of the immobilized urease, its activity was quantified by using the same composite of BCN for ten times in urea hydrolysis. All the experiments were conducted at room temperature with the same conditions of reaction. To determine the stability of free and immobilized ureases, they were stored for 40 days at laboratory temperature. Samples were taken weekly and the first day's activity was considered as $100 \%$.

\section{Results and Discussions}

3.1. SEM Image of BCN and Immobilized Urease. The obtained morphology of the synthesized nanofibers is shown in Figure 2(a) and the morphology changes of the cellulosic nanofibers after enzyme immobilization are illustrated using SEM images. SEM images are not witness of significant changes for synthesized nanofibers in different cultivation condition. As is demonstrated in Figure 2(a), the diameters of the nanofibers are varied between 30 and $70 \mathrm{~nm}$ which was calculated by SEM device (Philips XL-30 at $1 \mathrm{kV}$ ). Considerable changes can be observed in the nanofiber structure after enzyme immobilization (Figure 2(b)). Dimension of urease which has been published in protein data bank is about 1.5 angstroms [13], Accordingly, immobilized cross-linked urease cannot be identified in SEM images and it resulted in textile morphology which was reported in literatures [22]. The reason of this morphological change is the cross-linking of the urease enzymes in the nanospaces. Figure 2(b) shows the morphology of the immobilized enzymes through the nanofibers which illustrates that the cross-linked enzymes are not separated from the nanofibers and formed a stable structure.

Surface modifications can also bring along other benefits for enzyme immobilization. For example, the microstructure of surface modification layer can be modulated to tailor the behavior of immobilized enzymes [23] (e.g., the nanofibrous membrane system studied by Chen and Hsieh [24]). In their study, poly(acrylicacid) (PAA) was grafted onto the cellulose nanofibers for physical adsorption of enzyme. Gellike or brush-like PAA layer was formed on the nanofibers depending on the modes of surface-initiation. The results indicated that these two structures had distinct effects on the adsorption behavior and the activity of enzyme.

Krajewska compiles reports on immobilizations of ureases covering the last two decades, with few earlier reports 


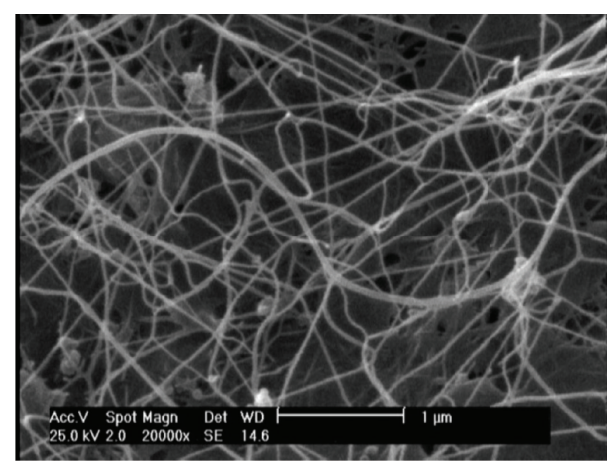

(a)

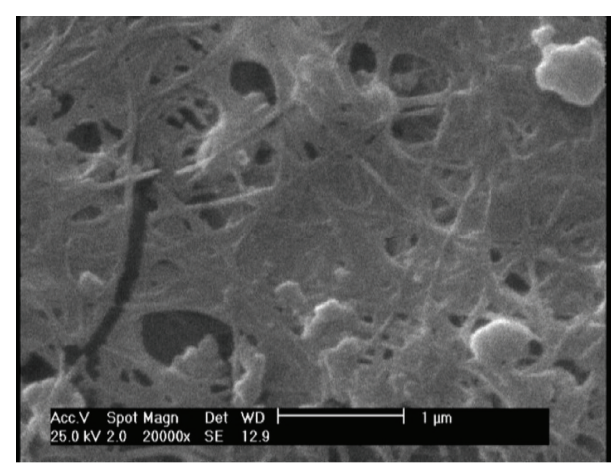

(b)

FIGURE 2: SEM images of (a) free and (b) urease immobilized bacterial cellulose nanofiber.

found important. The compilation was prepared with the intention to survey the range of techniques and support materials applied for urease immobilizations, but first and foremost to collect the properties of the enzymes resulting from the chosen immobilization procedures. This was done in the hope that it may provide useful guidance through the wealth of data available in the literature, but more importantly to develop an integrated perspective on how to customize the enzymes for their specific applications. The number of reports collected implies that there is an ongoing vivid search for such customized ureases, and they can play a decisive role in advancing their applications [25].

\subsection{Determination of the Protein Content of Immobilized Ure-} ase Nanofibers. The determination of protein content using Bradford method revealed that different protein content can be achieved within nanofibers which have been synthesized by different cultivation methods, Table 2 . As it is demonstrated in this table, there is major difference in amounts of urease immobilized in nanofibers. However, as it has been discussed, different stability and reusability occurred in various nanofibers and they are independent of its protein contents. Bradford method only shows the enzyme content of nanofibers including both active and nonactive urease, but enzyme assay which has been considered in this paper is an index of active enzyme. Results show that nanofiber which is synthesized in HS medium by Gluconacetobacter xylinum in 7 days (medium A) contains the highest amount of protein $\left(1.84 \mathrm{mg} \mathrm{mL}^{-1}\right)$ and nanofiber which is synthesized in molasses medium by Gluconacetobacter xylinum in 7 days (medium C) has the lowest value $\left(1.11 \mathrm{mg} \mathrm{mL}^{-1}\right)$ among synthesized nanofibers. In the current study activity of immobilized urease is measured in different $\mathrm{pH}$ and temperature, as a result efficiency of protein content of nanofibers is determined.

There have been many approaches to improve the enzyme stability: enzyme immobilization, enzyme modification, protein engineering, and medium engineering. Enzyme immobilization represents the attachment or incorporation of enzyme molecules onto or into large structures, via simple adsorption, covalent attachment, or encapsulation. In particular, the multipoint attachment between enzyme
TABLE 2: The effect of cultivation medium on protein content of BCN immobilized urease.

\begin{tabular}{lccc}
\hline $\begin{array}{l}\text { Experiment } \\
\text { number }\end{array}$ & Enzyme & $\begin{array}{c}\text { Cultivation condition } \\
\text { (based on Table 1) }\end{array}$ & $\begin{array}{c}\text { Protein content } \\
\left(\mathrm{mg} \mathrm{mL}^{-1}\right)\end{array}$ \\
\hline 1 & Urease & (A) & 1.84 \\
2 & Urease & $(\mathrm{B})$ & 1.39 \\
3 & Urease & $(\mathrm{C})$ & 1.11 \\
4 & Urease & (D) & 1.67 \\
\hline
\end{tabular}

molecules and host materials reduces protein unfolding and hence improves stability. Recent developments with crosslinked enzyme crystals (CLECs) and cross-linked enzyme aggregates (CLEAs) are based on multipoint attachment between enzyme crystals (or molecules) [15].

3.3. Effect of $p H$ on Urease Activity in Different BCN Cultivation Conditions. The effects of $\mathrm{pH}$ variation on the free and immobilized enzyme activity have been investigated. As it is seen in Figure 3, this effect was examined in the range of 6.0 to 9.0. The obtained results showed that the optimized $\mathrm{pH}$ for the free enzyme was 7.5 while this value for the immobilized enzyme on different BCNs was less than 7.5 in all cases. The decrease of the proper $\mathrm{pH}$ for enzyme activity in the immobilized form can be interpreted based on diffusional effects in the cellulosic nanofibers. The active urease enzyme produces the ammonium which is facing with the resistance of the nanofiber during its exit from the fiber. This resistance causes the difference between $\mathrm{pH}$ of the bulk and its value in the pores which results in variation of the optimized environmental $\mathrm{pH}$ of the free and immobilized urease.

The lowest optimum $\mathrm{pH}$ in this study belongs to medium (D) $(\mathrm{pH}=6.5)$. It seems that because of BCN structure, maximum resistance of the ammonium secretion from nanopores media to the substrate medium happens in the $\mathrm{BCN}$ which is synthesized in medium (D). Moreover, in $\mathrm{pH}$ of 9, synthesized BCN in medium (D) demonstrates the highest strength to deactivation and denaturation. It keeps 57 percent of its relative activity during the process. 


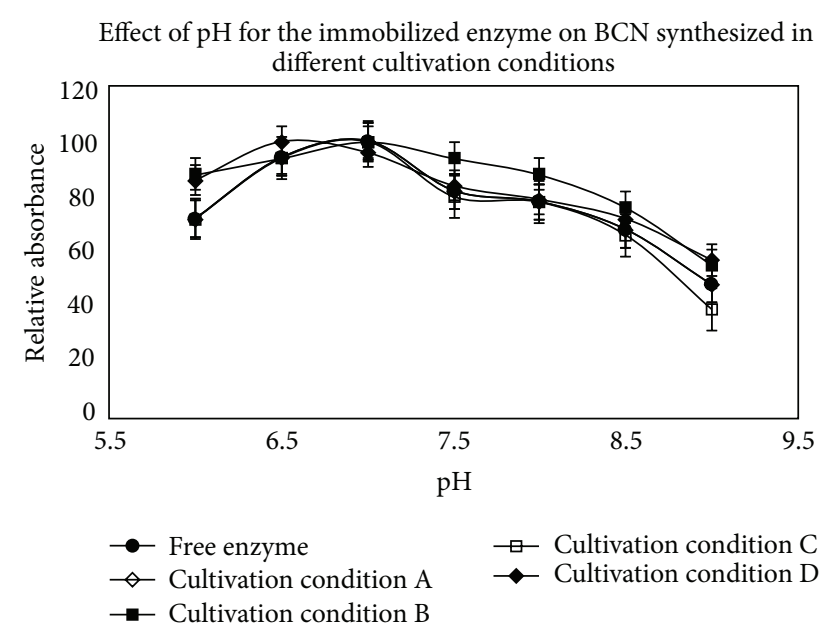

FIGURE 3: Effect of $\mathrm{pH}$ on the free and immobilized urease activity; the relative activities at the optimum $\mathrm{pH}$ were taken as $100 \%$ for free and immobilized urease, respectively.

Due to the variation of utilized supports and functional groups in literatures, different ranges of optimized $\mathrm{pH}$ for immobilized urease have been reported. In most of the revealed studies which have used the macro structures as immobilization supports, the results show an increase in optimum $\mathrm{pH}$ in comparison to the optimum activity range of free enzyme [26, 27]. In addition, there are cases showing that optimum $\mathrm{pH}$ range for immobilized urease was decreased when nanostructured supports were applied $[28,29]$.

Akkaya and Uslan considered the sequential immobilization of urease to glycidyl methacrylate grafted sodium alginate [13]. - $\mathrm{COOH}$ and epoxy groups of GMA (glycidyl methacrylate as an attractive monomer) grafted sodium alginate were selected for urease immobilization. Immobilization of urease was made from $-\mathrm{COOH}$ group at low $\mathrm{pH}$. Immobilization from epoxy group was made at high $\mathrm{pH}$. This way, enzyme immobilization could be done according to $\mathrm{pH}$ selectivity during immobilization.

3.4. Effect of Temperature on the Immobilized Enzyme. The effect of temperature on the free and immobilized enzyme activity has been studied in the range of 30 to $80^{\circ} \mathrm{C}$. As it is shown in Figure 4, the optimal temperature for both free and immobilized enzyme was around $50^{\circ} \mathrm{C}$ but the sensitivity of the immobilized enzyme to temperatures variations was less than the free enzyme in all cases, especially in higher temperature which may cause the enzyme denaturation. It should be noted that the nanopores immobilized enzymes, which are linked to each other and the matrix by glutaraldehyde, are the sources of some spatial limitation on the conformational changes of the enzyme. At the same time, it results in better performance of the immobilized enzyme in comparison to the free enzyme in higher temperature. As it is demonstrated in Figure 4, free and immobilized enzyme in different BCNs have almost the same trend before optimum temperature $\left(50^{\circ} \mathrm{C}\right)$, while, in higher temperatures, the synthesized $\mathrm{BCNs}$

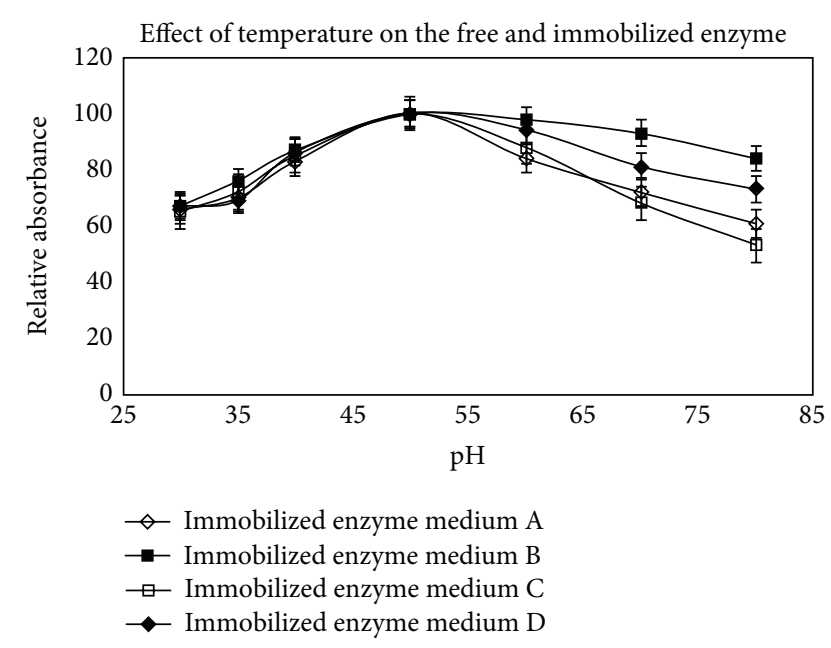

FIGURE 4: Effect of temperature on the free and immobilized urease activity; the relative activities at the optimum temperatures were taken as $100 \%$ for free and immobilized urease, respectively.

in medium (B) show better performance for immobilized enzyme.

Cross-linking of enzymes to each other and formation of enzymatic network decreases the possibility of their conformational change at temperatures above the optimum. In consequence, the enzyme almost retains its activity at temperatures above $50^{\circ} \mathrm{C}$ and decreases just about $21 \%$ at $80^{\circ} \mathrm{C}$ while the reduction is about $94 \%$ for the free enzyme.

Danial et al. characterize the immobilized urease on grafted alginate bead systems. This study evaluated the biological importance of immobilized urease enzyme over the free urease. The support material used for urease immobilization was alginate. Generally, the immobilization of urease in alginate gel showed a marked increase in $K_{m}$ and $V_{\max }$. However, the immobilized urease showed higher thermal stability than that of free enzyme. The rate of thermal inactivation of the immobilized enzyme decreased due to entrapment in gel matrix. Also, the activity of the immobilized urease was more stable in retention than that of the free enzyme during the storage in solution, although the activity of the immobilized enzyme was lower in comparison with the free enzyme. A stable immobilized system and long storage life are convenient for applications that would not be feasible with a soluble enzyme system. These results highlighted the technical and biochemical benefits of immobilized urease over the free enzyme [26].

The stability of enzyme against denaturation above the optimum temperature of the previous studies is presented in Table 3. Based on the results, the activity maintenance in present work is the best compared to the previous ones.

The immobilization of the urease in the nanospace of the supports has been used in this study. Consequently, the immobilization and cross-linking cause an increase in the resistance of urease against conformational changes.

3.5. Study on the Enzyme Stability. One of the main advantages of enzyme immobilization is the possibility of its 
TABLE 3: Effect of different temperatures on immobilized urease activity.

\begin{tabular}{|c|c|c|c|c|c|c|c|}
\hline \multirow{2}{*}{ Enzyme } & \multirow{2}{*}{ Immobilization matrix } & \multirow{2}{*}{$\begin{array}{l}\text { Method of } \\
\text { immobilization }\end{array}$} & \multirow{2}{*}{$\begin{array}{l}\text { Optimum } \\
\text { temperature }\end{array}$} & \multicolumn{3}{|c|}{ Enzyme activity in optimum $T+X^{\circ} \mathrm{C}$} & \multirow{2}{*}{ Reference } \\
\hline & & & & $10^{\circ} \mathrm{C}$ & $20^{\circ} \mathrm{C}$ & $30^{\circ} \mathrm{C}$ & \\
\hline Urease & BCN (Medium B) & Cross-linking & $50^{\circ} \mathrm{C}$ & $98 \%$ & $91 \%$ & $79 \%$ & Present work \\
\hline Urease & BCN (Medium A) & Cross-linking & $50^{\circ} \mathrm{C}$ & $84 \%$ & $72 \%$ & $61 \%$ & Present work \\
\hline Urease & BCN (Medium C) & Cross-linking & $50^{\circ} \mathrm{C}$ & $88 \%$ & $65 \%$ & $53 \%$ & Present work \\
\hline Urease & BCN (Medium D) & Cross-linking & $50^{\circ} \mathrm{C}$ & $94 \%$ & $81 \%$ & $73 \%$ & Present work \\
\hline Urease & Electrospun polyacrylonitrile & Covalent bonding & $50^{\circ} \mathrm{C}$ & $60 \%$ & $45 \%$ & $30 \%$ & {$[28]$} \\
\hline Urease & Nanostructured polymer & Covalent bonding & $30^{\circ} \mathrm{C}$ & $90 \%$ & - & - & [27] \\
\hline Urease & Sodium alginate & Cross-linking & $50^{\circ} \mathrm{C}$ & 60 & 30 & - & {$[26]$} \\
\hline Urease & Cellulosic cotton fibers & Covalent bonding & $35^{\circ} \mathrm{C}$ & 75 & - & - & {$[29]$} \\
\hline
\end{tabular}

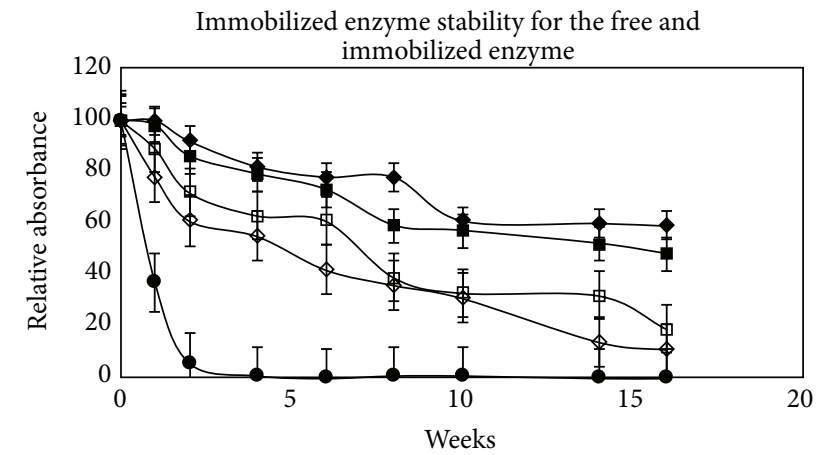

$\bullet$ Free enzyme

$\diamond$ Immobilized enzyme medium A

- Immobilized enzyme medium B

$\square$ Immobilized enzyme medium C

$\multimap$ Immobilized enzyme medium D

FIGURE 5: Operational stability of immobilized urease on different BCNs.

multiple use in the bioprocesses and the other one is their stability during a long period of time. As can be seen in Figure 5 with using the enzyme immobilized in medium (D) after 14 days, the enzyme activity decreased only $8 \%$ and, after 120 days, the reduction was only $41 \%$ (Figure 5 ). It should be mentioned that the free enzyme lost around $73 \%$ of its activity after 7 days in our laboratory condition $\left(28^{\circ} \mathrm{C}\right)$.

In 2003, a new synthetic approach was reported under the name of "single enzyme nanoparticles (SENs)," in which an organic-inorganic hybrid polymer network of a thickness of less than a few nanometers was built up from the surface of the enzyme [30]. Due to the small size of the resulting SENs, it is also possible to place them into nanoporous materials [31]. Traditionally, enzyme stabilization by adsorption in nanoporous media requires matching the pore size to that of the enzyme to retard enzyme unfolding. It has been shown to be of particular advantage if the radius of curvature for the pore is similar to that of native enzyme, thereby confining the enzyme and, furthermore, allowing multiple points of covalent attachment in the nanopore [5]. However, in the immobilization of SENs into nanoporous media, the modified enzyme molecules are already stabilized within the thin polymer network, and the pore size can be independently selected to provide other desirable attributes, such as rapid mass transfer to and from enzyme catalysts, with no concern for enzyme stabilization. Thus, larger pores can be selected that would not provide extended stabilization of an unmodified enzyme but allow for rapid diffusion.

The CNF (Cellulose Nanofibers) surface consists of mainly $-\mathrm{OH}$ functional group that can directly interact weakly with enzyme, and its binding can be improved by surface modification and interaction of chemical coupling that forms a strong and stable covalent immobilization of enzyme. The knowledge of covalent interaction for enzyme immobilization is important to provide more efficient interaction between CNF support and enzyme molecule. Enzyme immobilization onto CNF is having potential for improving enzymatic performance and production yield, as well as contributing toward green technology and sustainable sources [4].

3.6. Statistical Analysis. Based on the statistical analysis, whereas the $\mathrm{pH}$ increased, the effect of cultivation condition on urease activity was insignificant $(P$ value $>0.05)$. While the $\mathrm{pH}$ increased as well, the effect of temperature on urease activity was important $(P$ value $>0.05)$. According to $T$-value, the analysis showed that the $\mathrm{pH}$ in the range of 6.5 to 7 was considerable on the relative absorbance; however, $\mathrm{pH}$ more than 7 were significant while the temperature changed.

\section{Conclusion}

This study showed the success of cross-linked immobilization of urease on bacterial cellulosic nanofiber from Gluconacetobacter xylinum with an average nanofiber diameter of $30-70 \mathrm{~nm}$. The urease was immobilized on these nanofibers following the treatment of those with $\mathrm{NaOH}$ solutions. The enzyme was cross-linked by glutaraldehyde solution $(0.75 \%(\mathrm{w} / \mathrm{v}))$ which caused entrapment of urease in the bacterial nanofiber. Four different types of BCNs were synthesized for urease immobilization. Results showed that longer cultivation time led to better performance of immobilized urease in all $\mathrm{pH}$, temperature, stability, and reusability conditions. The SEM images revealed that the enzyme was entrapped in the nanofibers and confirmed the success of immobilization. Immobilized urease tolerated the changes in 
$\mathrm{pH}(5.5-9)$ and temperature $\left(30-80^{\circ} \mathrm{C}\right)$ significantly better than the free urease. In addition, it showed the improved storage stability (20 days) and retained almost $81 \%$ and $68 \%$ of initial activity after 15 and 20 cycles of reuse, respectively. Moreover, optimum $\mathrm{pH}$, reusability, and stability of immobilized urease on BCNs which were produced from molasses were higher than the BCNs from HS medium. However, the immobilized urease on BCNs which were produced from HS medium had better functionality in various ranges of temperature. This study provides an inexpensive, simple, efficient, and reliable technique for immobilization of urease on this novel nanofiber which may contribute to finding application in artificial kidney machines and their dialysate liquid regeneration systems.

\section{Conflict of Interests}

The authors declare that there is no conflict of interests regarding the publication of this paper.

\section{Acknowledgment}

The authors acknowledge Dr. Babaeipour for his kind and generous collaboration in bacterial cellulose nanofiber cultivation and biosynthesis.

\section{References}

[1] J. Kim, J. W. Grate, and P. Wang, "Nanobiocatalysis and its potential applications," Trends in Biotechnology, vol. 26, no. 11, pp. 639-646, 2008.

[2] L. Fjerbaek, K. V. Christensen, and B. Norddahl, "A review of the current state of biodiesel production using enzymatic transesterification," Biotechnology and Bioengineering, vol. 102, no. 5, pp. 1298-1315, 2009.

[3] K. R. Jegannathan, S. Abang, D. Poncelet, E. S. Chan, and P. Ravindra, "Production of biodiesel using immobilized lipasea critical review," Critical Reviews in Biotechnology, vol. 28, no. 4, pp. 253-264, 2008.

[4] S. Sulaiman, M. N. Mokhtar, M. N. Naim, A. S. Baharuddin, and A. Sulaiman, "A review: potential usage of cellulose nanofibers (CNF) for enzyme immobilization via covalent interactions," Applied Biochemistry and Biotechnology, vol. 175, no. 4, pp. 18171842, 2005.

[5] P. Wang, S. Dai, S. D. Waezsada, A. Y. Tsao, and B. H. Davison, "Enzyme stabilization by covalent binding in nanoporous solgel glass for nonaqueous biocatalysis," Biotechnology and Bioengineering, vol. 74, no. 3, pp. 249-255, 2001.

[6] J. Lee, Y. Lee, J. K. Youn et al., "Simple synthesis of functionalized superparamagnetic magnetite/silica core/shell nanoparticles and their application as magnetically separable highperformance biocatalysts," Small, vol. 4, no. 1, pp. 143-152, 2008.

[7] X.-J. Huang, A.-G. Yu, J. Jiang, C. Pan, J.-W. Qian, and Z.$\mathrm{K} . \mathrm{Xu}$, "Surface modification of nanofibrous poly(acrylonitrileco-acrylic acid) membrane with biomacromolecules for lipase immobilization," Journal of Molecular Catalysis B: Enzymatic, vol. 57, no. 1-4, pp. 250-256, 2009.

[8] B. C. Kim, S. Nair, J. Kim et al., "Preparation of biocatalytic nanofibres with high activity and stability via enzyme aggregate coating on polymer nanofibres," Nanotechnology, vol. 16, no. 7, p. S382, 2005.
[9] C. Castro, R. Zuluaga, J.-L. Putaux, G. Caro, I. Mondragon, and P. Gañán, "Structural characterization of bacterial cellulose produced by Gluconacetobacter swingsii sp. from Colombian agroindustrial wastes," Carbohydrate Polymers, vol. 84, no. 1, pp. 96-102, 2011.

[10] C. Mateo, J. M. Palomo, G. Fernandez-Lorente, J. M. Guisan, and R. Fernandez-Lafuente, "Improvement of enzyme activity, stability and selectivity via immobilization techniques," Enzyme and Microbial Technology, vol. 40, no. 6, pp. 1451-1463, 2007.

[11] Z.-G. Wang, L.-S. Wan, Z.-M. Liu, X.-J. Huang, and Z.-K. Xu, "Enzyme immobilization on electrospun polymer nanofibers: an overview," Journal of Molecular Catalysis B: Enzymatic, vol. 56, no. 4, pp. 189-195, 2009.

[12] P. Wang, "Nanoscale biocatalyst systems," Current Opinion in Biotechnology, vol. 17, no. 6, pp. 574-579, 2006.

[13] A. Akkaya and A. H. Uslan, "Sequential immobilization of urease to glycidyl methacrylate grafted sodium alginate," Journal of Molecular Catalysis B: Enzymatic, vol. 67, no. 3-4, pp. 195-201, 2010.

[14] D. Brady and J. Jordaan, "Advances in enzyme immobilisation," Biotechnology Letters, vol. 31, no. 11, pp. 1639-1650, 2009.

[15] J. Kim, J. W. Grate, and P. Wang, "Nanostructures for enzyme stabilization," Chemical Engineering Science, vol. 61, no. 3, pp. 1017-1026, 2006.

[16] R. Schoevaart, M. W. Wolbers, M. Golubovic et al., "Preparation, optimization, and structures of cross-linked enzyme aggregates (CLEAs)," Biotechnology and Bioengineering, vol. 87, no. 6, pp. 754-762, 2004.

[17] S. Hestrin and M. Schramm, "Synthesis of cellulose by Acetobacter xylinum. 2. Preparation of freeze-dried cells capable of polymerizing glucose to cellulose," Biochemical Journal, vol. 58, no. 2, pp. 345-352, 1954.

[18] T. G. Chiciudean, A. Stoica-Guzun, T. Dobre, and M. Van Tooren, "High-strength epoxy bacterial cellulose based composites," Materiale Plastice, vol. 48, no. 2, pp. 159-163, 2011.

[19] X.-J. Huang, P.-C. Chen, F. Huang, Y. Ou, M.-R. Chen, and Z.$\mathrm{K}$. Xu, "Immobilization of Candida rugosa lipase on electrospun cellulose nanofiber membrane," Journal of Molecular Catalysis B: Enzymatic, vol. 70, no. 3-4, pp. 95-100, 2011.

[20] T. T. Ngo, A. P. H. Phan, C. F. Yam, and H. M. Lenhoff, "Interference in determination of ammonia with the hypochloritealkaline phenol method of berthelot," Analytical Chemistry, vol. 54, no. 1, pp. 46-49, 1982.

[21] M. M. Bradford, "A rapid and sensitive method for the quantitation of microgram quantities of protein utilizing the principle of protein-dye binding," Analytical Biochemistry, vol. 72, no. 1-2, pp. 248-254, 1976.

[22] Y. S. Song, H. Y. Shin, J. Y. Lee, C. Park, and S. W. Kim, “ $\beta$-Galactosidase-immobilised microreactor fabricated using a novel technique for enzyme immobilisation and its application for continuous synthesis of lactulose," Food Chemistry, vol. 133, no. 3, pp. 611-617, 2012.

[23] L.-S. Wan, B.-B. Ke, J. Wu, and Z.-K. Xu, "Catalase immobilization on electrospun nanofibers: effects of porphyrin pendants and carbon nanotubes," Journal of Physical Chemistry C, vol. 111, no. 38, pp. 14091-14097, 2007.

[24] H. Chen and Y.-L. Hsieh, "Enzyme immobilization on ultrafine cellulose fibers via poly(acrylic acid) electrolyte grafts," Biotechnology and Bioengineering, vol. 90, no. 4, pp. 405-413, 2005.

[25] B. Krajewska, "Ureases. II. Properties and their customizing by enzyme immobilizations: a review," Journal of Molecular Catalysis B: Enzymatic, vol. 59, no. 1-3, pp. 22-40, 2009. 
[26] E. N. Danial, A. H. Hamza, and R. H. Mahmoud, "Characteristics of immobilized urease on grafted alginate bead systems," Brazilian Archives of Biology and Technology, vol. 58, no. 2, pp. 147-153, 2015.

[27] K. Gabrovska, J. Ivanov, I. Vasileva, N. Dimova, and T. Godjevargova, "Immobilization of urease on nanostructured polymer membrane and preparation of urea amperometric biosensor," International Journal of Biological Macromolecules, vol. 48, no. 4, pp. 620-626, 2011.

[28] A. Daneshfar, T. Matsuura, D. Emadzadeh, Z. Pahlevani, and A. F. Ismail, "Urease-carrying electrospun polyacrylonitrile mat for urea hydrolysis," Reactive \& Functional Polymers, vol. 87, pp. 37-45, 2015.

[29] M. Monier and A. M. A. El-Sokkary, "Modification and characterization of cellulosic cotton fibers for efficient immobilization of urease," International Journal of Biological Macromolecules, vol. 51, no. 1-2, pp. 18-24, 2012.

[30] J. Kim and J. W. Grate, "Single-enzyme nanoparticles armored by a nanometer-scale organic/inorganic network," Nano Letters, vol. 3, no. 9, pp. 1219-1222, 2003.

[31] J. Kim, H. Jia, C.-W. Lee et al., "Single enzyme nanoparticles in nanoporous silica: a hierarchical approach to enzyme stabilization and immobilization," Enzyme and Microbial Technology, vol. 39, no. 3, pp. 474-480, 2006. 

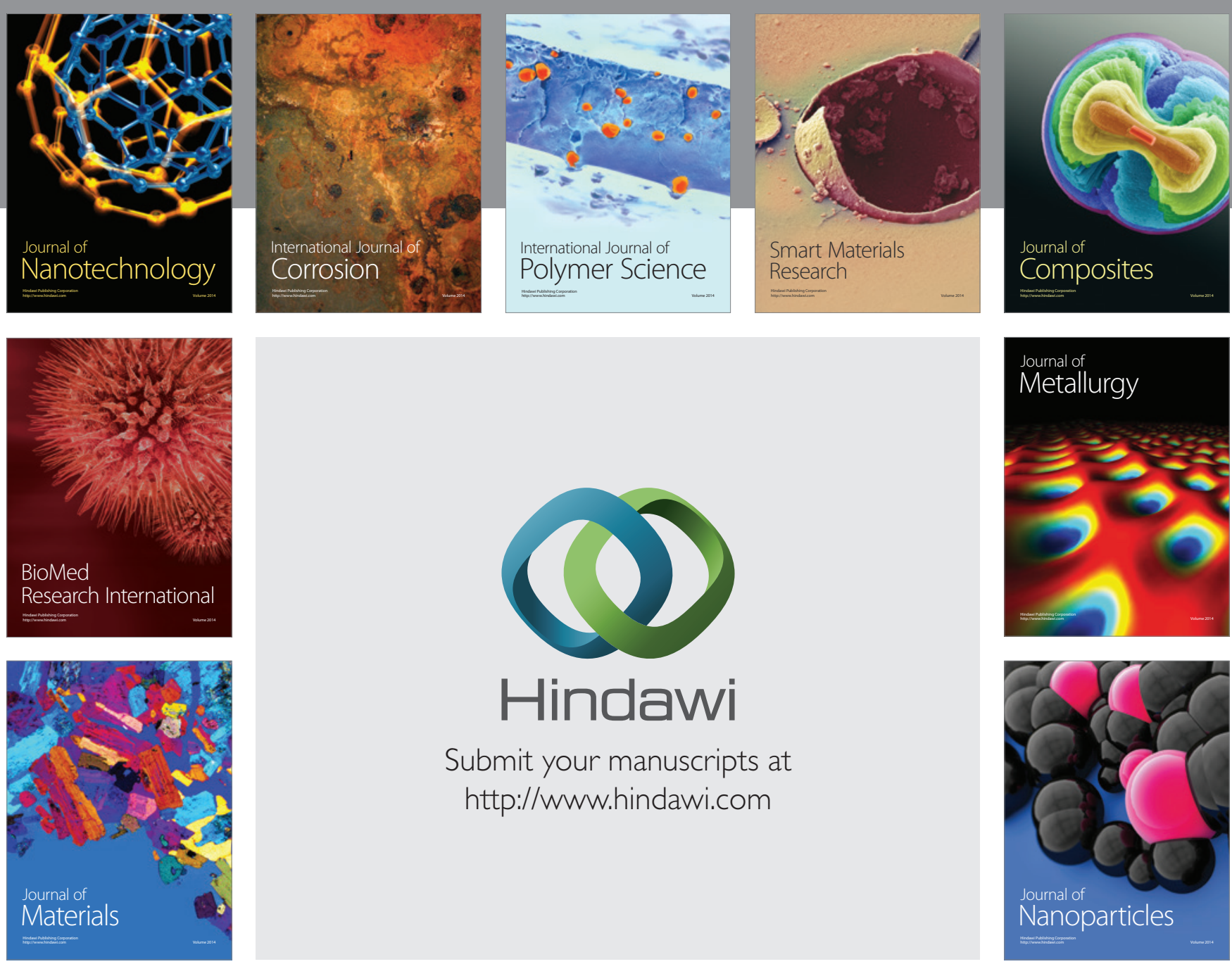

Submit your manuscripts at http://www.hindawi.com
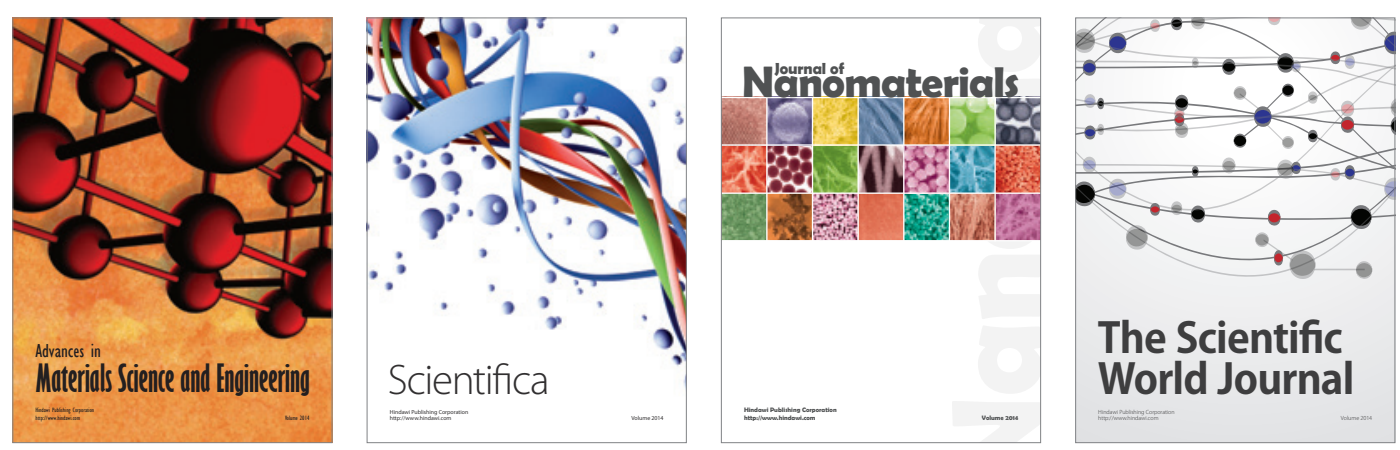

\section{The Scientific World Journal}
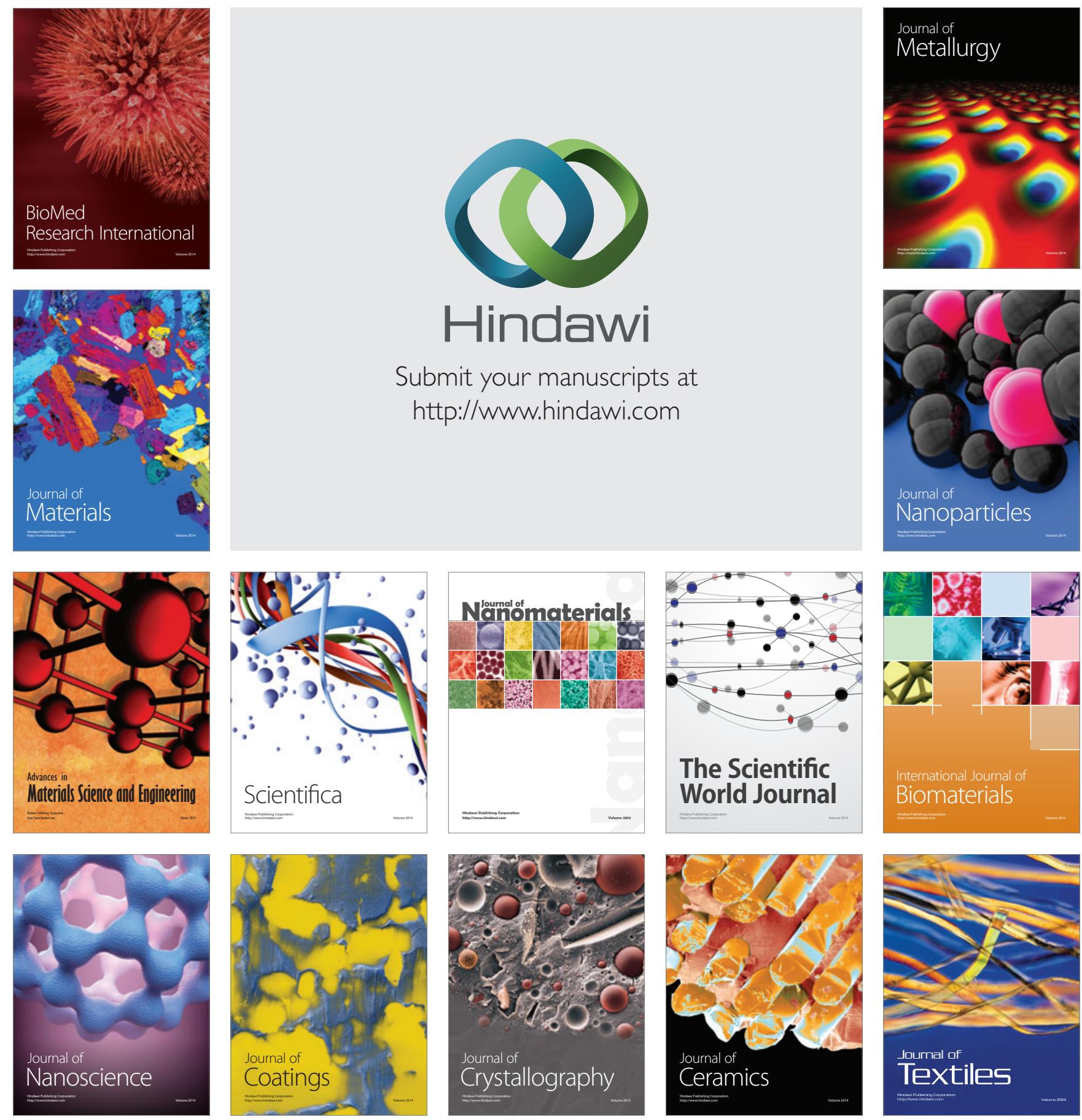